\title{
Bamboo Forest Water Use Efficiency in the Yangtze River Delta Region, China
}

\author{
Fan Wang ${ }^{1}$, Hong Jiang ${ }^{1,2, *}$, Xiaofeng Chen $^{2}$, and Xiaodong $\mathrm{Niu}^{2}$ \\ ${ }^{1}$ Jiangsu Provincial Key Laboratory of Geographic Information Science and Technology, International Institute for Earth System \\ Science, Nanjing University, Nanjing, China \\ ${ }^{2}$ State Key Laboratory of Subtropical Forest Science \& Zhejiang Province Key Laboratory of Carbon Cycling in Forest \\ Ecosystems and Carbon Sequestration, Zhejiang Agriculture and Forest University, Hangzhou, Zhejiang, China
}

Received 13 September 2015, revised 2 January 2016, accepted 7 February 2016

\begin{abstract}
An eddy covariance technique was used to measure the gross primary productivity (GPP), evapotranspiration (ET), and water use efficiency (WUE) during the 2011 - 2014 period over a moso bamboo forest at a site in Anji (AJ), China. WUE declined during the severe summer drought of 2013 when the vapor pressure deficit (VPD) was above $15 \mathrm{hPa}$, and was significantly higher than the average value. At AJ the average annual GPP, ET, and WUE were $1522 \pm 73 \mathrm{C} \mathrm{m}^{-2}$ year-1 $^{-1}, 693 \pm 41 \mathrm{~kg}$ $\mathrm{H}_{2} \mathrm{O} \mathrm{m}^{-2}$ year $^{-1}$, and $2.21 \pm 0.23 \mathrm{~g} \mathrm{C} \mathrm{kg}^{-1} \mathrm{H}_{2} \mathrm{O}$, respectively. GPP and ET were closely correlated at AJ, with $\mathrm{R}^{2}$ equal to 0.64 . The monthly GPP and ET showed strong positive linear, exponential or quadratic polynomial correlations to meteorological variables, including air temperature (Ta), net radiation (Rn), and VPD. WUE was negatively correlated to VPD, with $36.3 \%$ of the variation in WUE explained by VPD. This study contributes to the understanding of the carbon and water cycle response mechanisms in forest ecosystems in the climate change context and is significant in relation to forest carbon sequestration management.
\end{abstract}

Key words: Gross primary productivity (GPP), Evapotranspiration (ET), Water use efficiency (WUE), Eddy covariance (EC), Climatic factors

Citation: Wang, F., H. Jiang, X. Chen, and X. Niu, 2016: Bamboo forest water use efficiency in the Yangtze River Delta region, China. Terr. Atmos. Ocean. Sci., 27, 981-989, doi: 10.3319/TAO.2016.02.07.01(Hy)

\section{INTRODUCTION}

The establishment of tree plantations is a potential approach to reducing atmospheric carbon dioxide concentrations to mitigate climate change (Cai et al. 2011; Zhou et al. 2014). However, carbon storage gains correspond to an amount of water loss. Carbon and water cycles are closely related in the terrestrial ecosystem because the exchange of carbon dioxide and water vapor between the biosphere and atmosphere are both controlled by stomata (Beer et al. 2009). Water use efficiency (WUE), the ratio of gross primary productivity (GPP) to evapotranspiration (ET), can be used to quantify this coupling relationship (Yu et al. 2004; Tang et al. 2014; Wang et al. 2015; Zhu et al. 2015). A better understanding of WUE will provide an alternative approach for carbon budget assessment (Beer et al. 2007, 2010). Meanwhile, understanding the GPP, ET, WUE char-

\footnotetext{
* Corresponding author

E-mail:jianghong_china@hotmail.com
}

acteristics, and their relationship with related environmental factors can greatly enhance our knowledge of their control processes as well as the ability to predict how climate change may affect the carbon and water budgets (Reichstein et al. 2007; Hu et al. 2008).

Eddy-covariance (EC) flux tower networks with their associated meteorological measurements have provided an opportunity to quantify ET, GPP, and WUE across a wide range of forest ecosystems, including Mediterranean evergreen forest (Reichstein et al. 2002), temperate broadleaved Korean pine mixed forest (Yu et al. 2008; Zhu et al. 2014), Douglas-fir stand (Ponton et al. 2006; Jassal et al. 2009), warm-temperate mixed plantation (Tong et al. 2014), and boreal forests (Ge et al. 2014; Kotani et al. 2014). To our knowledge, the ET, GPP, and WUE characteristics of bamboo forests are scarce in the literature.

Bamboo stands are one of the important forest types of the world and are distributed in the tropical, subtropical, and 
warm temperate regions ( $\mathrm{Lu}$ et al. 2014). In China, bamboo stands account for 4.99 million hectares, which is $2.5 \%$ of the total forest area of China and 39\% of the world bamboo forest area (SFAPRC 2005). From the late 1970s to early this century, the area of bamboo stands in China has experienced a surge of $51.40 \%$ (Chen et al. 2009). According to the statistical data obtained from a previous National Forestry Inventory, about $98 \%$ of all bamboo stands are distributed in southern China. Among the total area, Fujian, Jiangxi, and Zhejiang provinces account for half of these stands.

The carbon and water flux EC measurements were conducted in a moso bamboo forest. Previous studies have shown that the moso bamboo forest has strong capacity for storing carbon (Zhou and Jiang 2004). However, comprehensive studies on the relationship between carbon gain and water loss and their climatic controls at the ecosystem scale are lacking.

The objective of this paper is: (1) to characterize the seasonal and inter-annual pattern of GPP, ET, and WUE of a bamboo forest in the Yangtze River Delta region, China to better understand the relationship between carbon gain and water loss; (2) investigate the environmental variable effects on GPP, ET, and WUE.

\section{MATERIALS AND METHODS}

\subsection{Site Description}

Experimental data were observed at the Anji (AJ) site, China. AJ is located at $30^{\circ} 28^{\prime} \mathrm{N}, 119^{\circ} 40^{\prime} \mathrm{E}$. The AJ elevation is $380 \mathrm{~m}$. AJ sites experience a subtropical monsoon climate. The mean annual precipitation at $\mathrm{AJ}$ is $1270 \mathrm{~mm}$, the annual mean temperature is $16.6^{\circ} \mathrm{C}$ and the soil type is yellow loam. The height and diameter at breast height of moso bamboo are $13-20 \mathrm{~m}$ and $12-18 \mathrm{~cm}$, respectively.

\subsection{Field Measurements}

Field measurements were conducted from 2011 2014. Carbon and water fluxes were both measured with EC systems consisting of open-path infrared gas analyzers (Li-7500; Licor Inc., Lincoln, NB, USA) and a 3-D sonic anemometer (CSAT3; Campbell Scientific Inc., Logan, UT, USA). The EC systems were mounted $38 \mathrm{~m}$ above ground at AJ. A data logger (CR1000; Campbell Scientific Inc., Logan, UT, USA) recorded the EC signals at $10 \mathrm{~Hz}$ for archiving and on-line turbulence statistics computation.

Routine meteorological variables were measured simultaneously with the eddy fluxes. Air humidity and air temperature were measured with probes (HMP45C, Vaisala, Helsinki, Finland) at different heights. They were installed at 1,7 , and $38 \mathrm{~m}$. Net radiation was recorded with a radiometer (CNR4, Kipp \& Zonen) at a height of $38 \mathrm{~m}$. Soil temperature was monitored using thermocouple probes (109, Campbell Scientific Inc., Logan, UT, USA). Soil water content was measured using water content reflectometers (CS616, Campbell Scientific Inc., Logan, UT, USA). These instruments were mounted at depths of $0.05,0.5$, and $1 \mathrm{~m}$. All of these apparatuses were controlled with a data logger (CR1000; Campbell Scientific Inc., Logan, UT, USA). The data output was 30-min mean data. The monthly meteorological factor value was computed by block averaging over $30 \mathrm{~min}$.

\subsection{Data Processing and the Calculation of WUE}

2-D coordination rotation (McMillen 1988) and WebbPearman-Leuning (WPL) correction (Webb et al. 1980) were applied to obtain half-hourly mean water vapor and $\mathrm{CO}_{2}$ fluxes. All abnormal data, caused by instrument malfunctions and weather effects, such as rain and dew, were deleted. Missing data of less than 2 hours were filled using linear interpolation. Large gaps (more than 2 hours) were filled using the mean diurnal variation method (Falge et al. 2001). The monthly value of both fluxes was integrated from the half-hourly data.

The WUE was calculated as:

$\mathrm{WUE}=\mathrm{GPP} / \mathrm{ET}$

Where ET was obtained directly using the EC technique. GPP was calculated as

$\mathrm{GPP}=\mathrm{RE}-\mathrm{NEE}$

Where the net ecosystem carbon dioxide exchange (NEE) was measured directly using the EC technique. Ecosystem respiration (RE) during the nighttime was equal to NEE in magnitude, while RE during the daytime was extrapolated from the nighttime equation and daytime soil temperature to a depth of $5 \mathrm{~cm}$ (Reichstein et al. 2005; Lasslop et al. 2010).

\subsection{Statistical Analysis}

The GPP, ET, and WUE relationships with their climatic variables, including net radiation $(\mathrm{Rn})$, air temperature (Ta), and vapor pressure deficit (VPD) were evaluated using the best curve-fitting model with the highest determination coefficient. The relationship between GPP, ET, and climatic variables were fitted with linear, exponential growth or quadratic polynomial equations, while the relationship between WUE and VPD was fitted with linear equations.

\section{RESULTS}

\subsection{Environment Conditions}

The seasonal variations in climatic variables are shown in Fig. 1. In general, the net radiation value increased 
gradually from January to May, but there was a decline in June. The decline in net radiation in June was likely due to the specific weather conditions. Generally, it was persistently overcast with rain in June in this region. Net radiation reached its maximum in July, after which the net radiation value declined gradually. However, the seasonal variation in $\mathrm{Rn}$ in 2014 was different from the preceding 3 years. In 2014 the seasonal variation in $\mathrm{Rn}$ showed a unimodal pattern, with its maximum peak in July. The seasonal variation in air temperature showed a unimodal pattern, with its maximum occurring in July. It is noteworthy that the monthly VPD was significantly higher in July and August 2013, with values exceeding $15 \mathrm{hPa}$. The high VPD values were in synchronicity with the summer drought that occurred at this site. Without sufficient water supply the soil water content inevitably dropped.

\subsection{Seasonal and Interannual Variation in GPP, ET, and WUE}

In general, both GPP and ET achieved their maximum
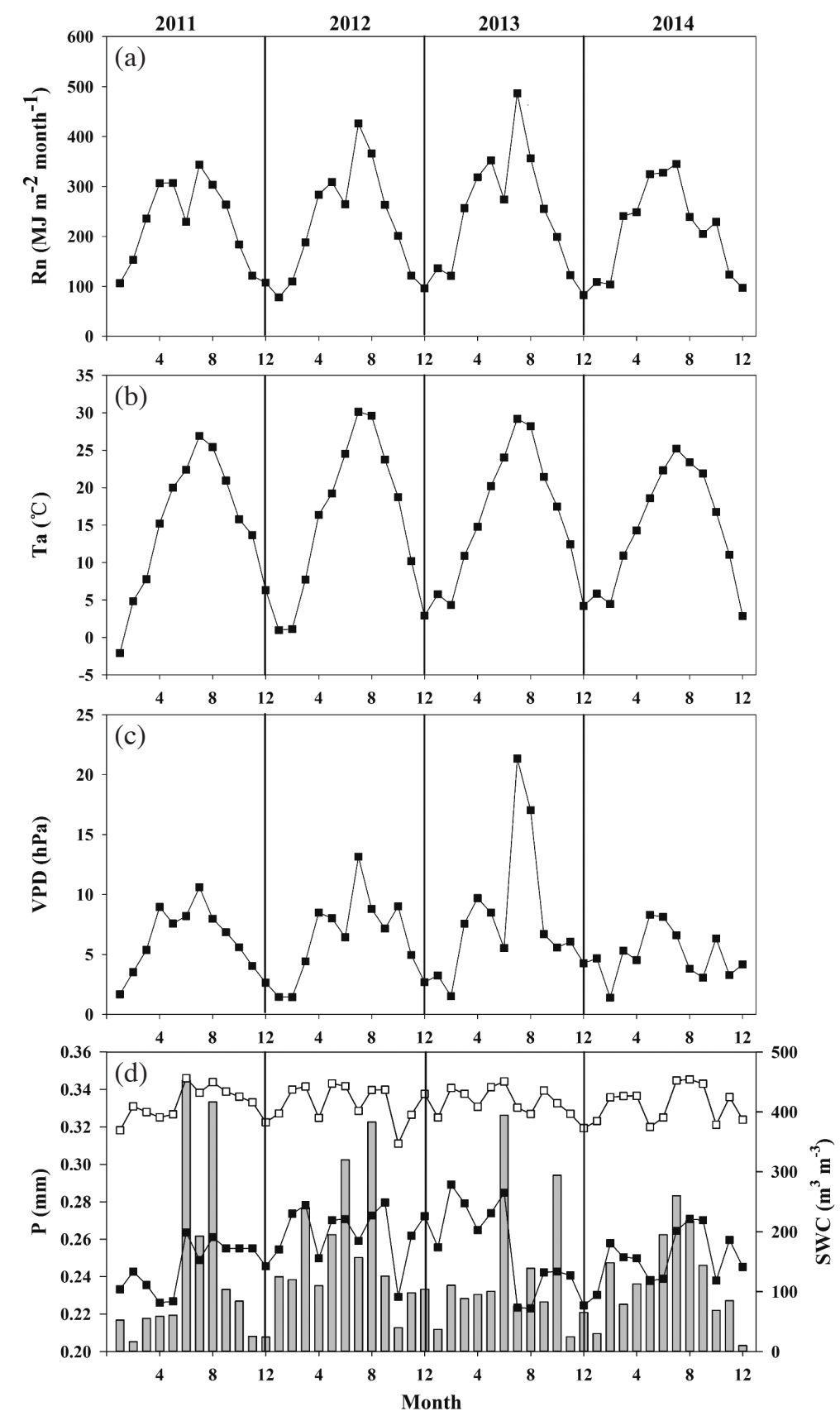

Fig. 1. Seasonal variations of (a) monthly net radiation (Rn), (b) monthly mean air temperature (Ta), (c) monthly vapor pressure deficit (VPD), (d) precipitation (P, columns), and monthly mean soil water content (SWC, closed and open squares are SWC at depths of 5 and $50 \mathrm{~cm}$, respectively) at Anj. 
in July (Fig. 2). However, the seasonal variation in WUE was more complicated and did not show any pattern. It should be noted that in 2013 the AJ site experienced a summer drought. The monthly mean VPD was over $15 \mathrm{hPa}$ in both July and August and was significantly higher than normal. However, GPP did not drop immediately with the drought. The GPP value showed a pronounced decrease in the following month. Different from GPP, ET had a rapid response to the summer drought. The ET value went up to over $105 \mathrm{~mm} \mathrm{month}^{-1}$. Meanwhile, monthly WUE obtained its minimum of $1.27 \mathrm{~g} \mathrm{C} \mathrm{kg}^{-1}$
$\mathrm{H}_{2} \mathrm{O}$. On an annual scale, the GPP minimum and ET maximum both occurred in 2013 (Table 1).

\subsection{Coupling Between GPP and ET}

Strong correlations between monthly GPP and ET were found across various biome types (Law et al. 2002; Yu et al. 2008; Brümmer et al.2012). When we examined the relationship between GPP and ET the values that occurred in July and August 2013 were excluded because the environmental
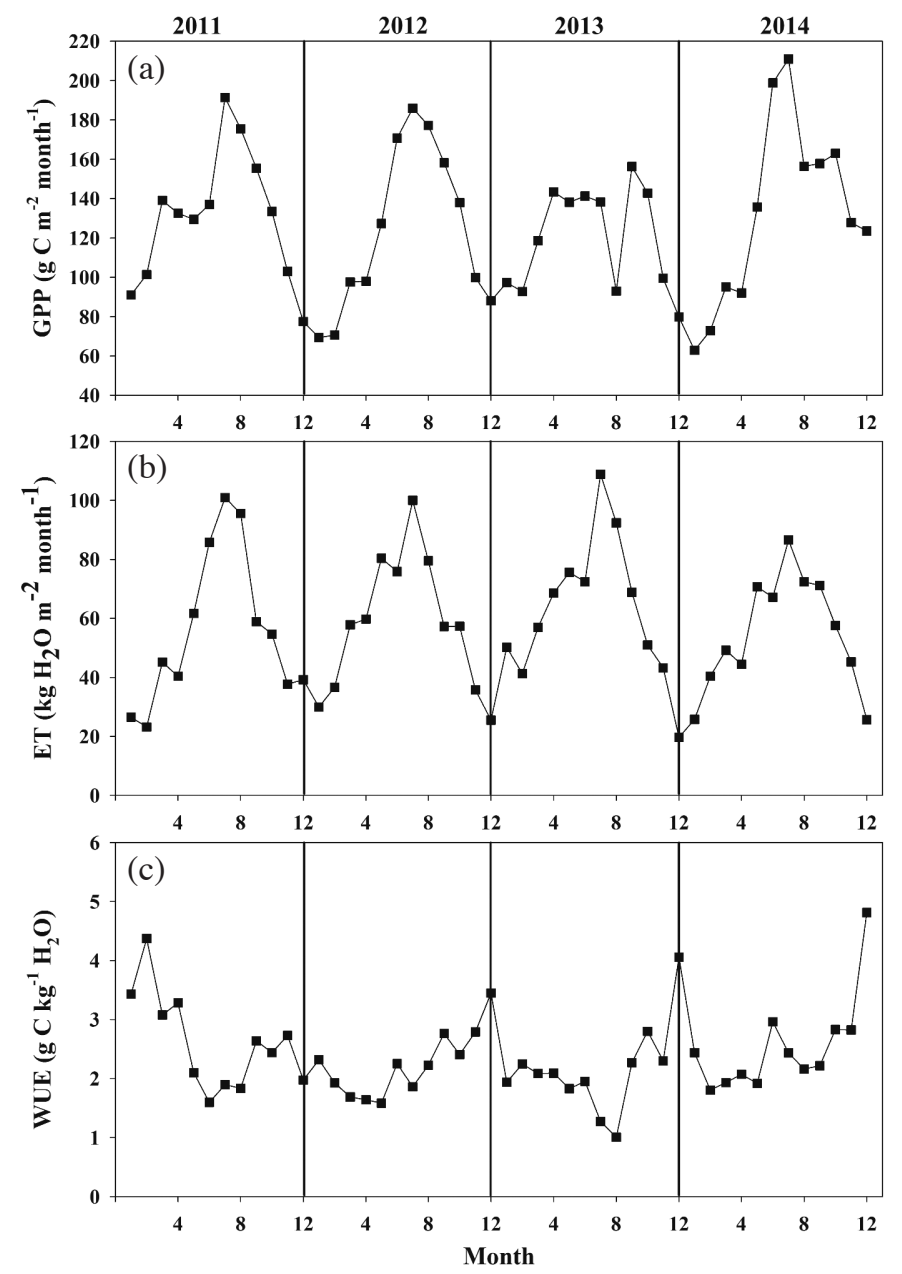

Fig. 2. The seasonal variation of (a) monthly gross primary productivity (GPP), (b) monthly evapotranspiration (ET), and (c) monthly water use efficiency (WUE) at Anji.

Table 1. Estimates of annual GPP, ET, and WUE based on eddy covariance measurements.

\begin{tabular}{cccc}
\hline Year & GPP $\left(\mathbf{g ~ C ~ m}^{-2}\right.$ year $\left.^{-1}\right)$ & ET $\left(\mathrm{kg} \mathrm{H}_{\mathbf{2}} \mathbf{O ~ m}^{-2}\right.$ year $\left.^{-1}\right)$ & WUE $\left(\mathbf{g ~ C ~ k g}^{-1} \mathbf{H}_{\mathbf{2}} \mathbf{O}\right)$ \\
\hline 2011 & 1567 & 670 & 2.34 \\
2012 & 1481 & 696 & 2.13 \\
2013 & 1441 & 749 & 1.92 \\
2014 & 1597 & 656 & 2.43 \\
\hline
\end{tabular}


conditions in those months were significantly different from other periods (Fig. 1). GPP and ET were closely correlated with $\mathrm{R}^{2}$ of 0.642 (Fig. 3).

\subsection{Meteorological Factor Effects on GPP and ET}

Previous studies have shown that GPP and ET were both influenced by climatic variables (Tong et al. 2014; Wang et al. 2015). In this study, the GPP relationships with $\mathrm{Ta}$ and $\mathrm{Rn}$ were fitted with exponential growth equations, while the relationship between GPP and VPD was fitted with a quadratic polynomial equation. ET increased linearly with an increase in meteorological variables. Compared to GPP, ET was more closely related to environmental factors, with $\mathrm{R}^{2}$ of ET and environmental factors consistently higher than those of GPP and environmental factors (Fig. 4). Similar to section 3.3 the values that occurred in July and August 2013 were also excluded when we examined the meteorological factor effects on GPP and ET.

\subsection{Effect of VPD on WUE}

The negative relationship between WUE and VPD is theoretically based (Farquhar and Richards 1984). In recent decades a large number of researchers have demonstrated that WUE also has a strong negative correlation with VPD on ecosystems (Law et al. 2002; Scanlon and Albertson 2004; Ponton et al. 2006; Song et al. 2006; Zhao et al. 2007; Kuglitsch et al. 2008; Testi et al. 2008; Tong et al. 2009; Yang et al. 2010). In the current study as VPD increased, WUE linearly decreased, with $36.3 \%$ of the variation in WUE explained by VPD (Fig. 5). It should be noted that the WUE and VPD values that occurred in the winter (January, February, and December) were rejected because plants are inactive in winter.

\section{DISCUSSION}

\subsection{Comparison of this Study with Other Forest Ecosystems}

Table 2 lists the comparisons in this study with those reported in other forest ecosystems. The WUE of this bamboo forest was lower than the results for a Mediterranean Eucalyptus plantation (Rodrigues et al. 2011) and a subtropical coniferous plantation (Yu et al. 2008), but higher than the results for a warm-temperate mixed plantation (Tong et al. 2014) and a subtropical evergreen broad-leaved forest (Yu et al. 2008), but were comparable to the result for a white pine ecosystem (Arain and Restrepo-Coupe 2005).

Compared with the results of Tong et al. (2014) for a warm-temperate mixed plantation, the carbon and water flux responses to meteorological variables were quite different. This was likely caused by the difference in climate conditions and species composition. This indicates that more studies on the climatic variables effect on carbon and water fluxes need to be conducted across a wide range of ecosystems.

\subsection{Effect of Summer Drought on WUE}

With a projected increase in the frequency and severity of droughts in the mid and high latitudes (Thomas et al. 2009), more attention has been paid to research into the seasonal drought effect on WUE. Previous studies showed inconsistent results. Vickers et al. (2012) found that the WUE at a mature ponderosa pine forest and a young plantation both increased during the summer drought. In contrast, other studies suggested that WUE decreases in response to summer drought conditions (Reichstein et al. 2002; Kotani et al. 2014; Mi et al. 2014; Zeri et al. 2014). While the discrepancy in WUE response to drought conditions was likely caused by the drought intensity. The WUE increases when the drought intensity is moderate while it tends to decrease under severe drought conditions (Lu and Zhuang 2010). This explanation is proven in this study. The WUE declined during the severe summer drought of 2013 when the VPD exceeded $15 \mathrm{hPa}$, which was significantly higher than the average value. Furthermore, the decrease in WUE during the severe drought was likely due to patchy stomatal closure, changes in photosynthesis physiological capacities, decreases in mesophyll conductance for $\mathrm{CO}_{2}$ and photoinhibition (Reichstein et al. 2002).

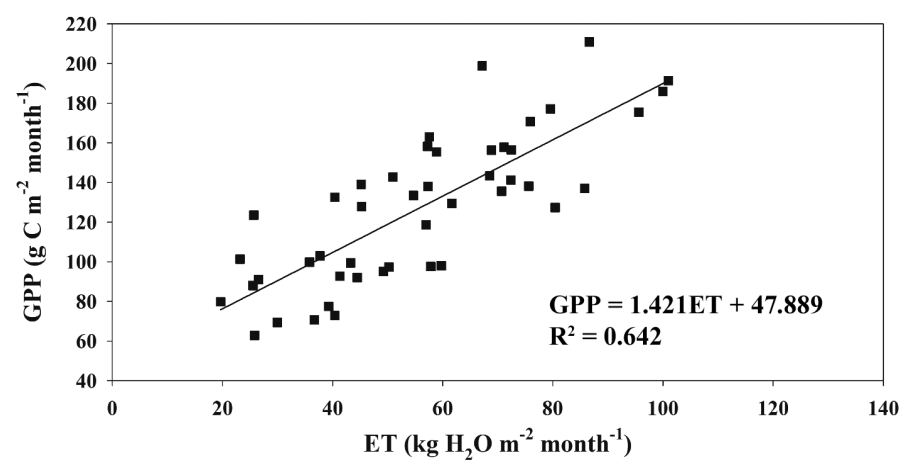

Fig. 3. Relationship between monthly gross primary productivity (GPP) and monthly evapotranspiration (ET) at Anji. 

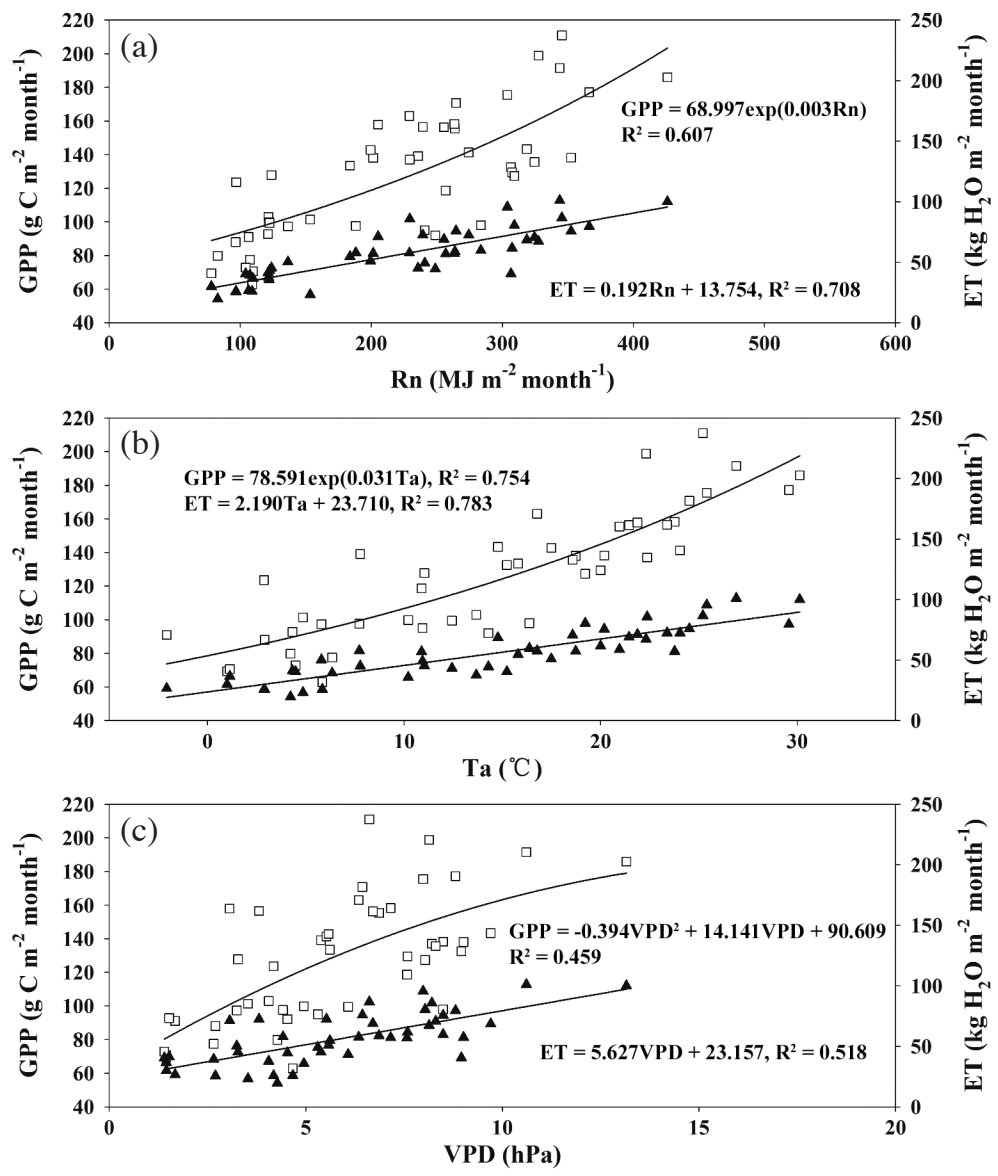

Fig. 4. The relationship between gross primary productivity (GPP, open squares), evapotranspiration (ET, closed triangles), and climatic factors [(a) net radiation (Rn), (b) air temperature (Ta), and (c) vapor pressure deficit (VPD)] at Anji.

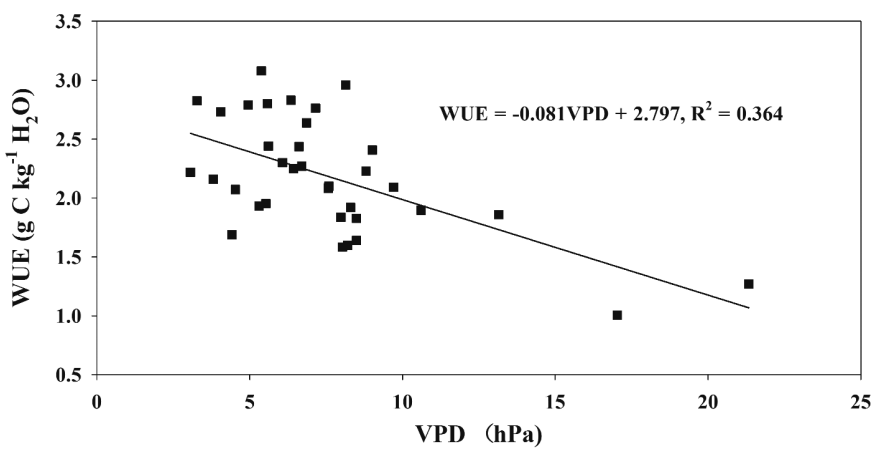

Fig. 5. The relationship between water use efficiency (WUE) and vapor pressure deficit (VPD) at Anji.

Table 2. Comparison of GPP, ET, and WUE in this study with those reported on other forest ecosystems.

\begin{tabular}{|c|c|c|c|c|c|}
\hline Ecosystem & Latitude & $\begin{array}{c}\text { GPP } \\
\left(\mathrm{g} \mathrm{C} \mathrm{m}^{-2} \mathbf{y r}^{-1}\right) \\
\end{array}$ & $\begin{array}{c}\text { ET } \\
\left(\mathrm{kg} \mathrm{H}_{2} \mathrm{O} \mathrm{m}^{-2} \mathrm{yr}^{-1}\right) \\
\end{array}$ & $\begin{array}{c}\text { WUE } \\
\left(\mathrm{g} \mathrm{C} \mathrm{kg}^{-1} \mathrm{H}_{2} \mathrm{O}\right) \\
\end{array}$ & Reference \\
\hline White pine & $42^{\circ} 42^{\prime} 44^{\prime \prime} \mathrm{N}$ & 1442 & 422 & 2.15 & Arain and Restrepo-Coupe (2005) \\
\hline Subtropical coniferous plantation & $26^{\circ} 44^{\prime} \mathrm{N}$ & 1555 & $632 \pm 144$ & 2.53 & Yu et al. (2008) \\
\hline Subtropical evergreen broad-leaved forest & $23^{\circ} 10^{\prime} \mathrm{N}$ & 1287 & $685 \pm 29$ & 1.88 & Yu et al. (2008) \\
\hline Eucalyptus plantation & $38^{\circ} 38^{\prime} \mathrm{N}$ & 1571 & 606 & 2.87 & Rodrigues et al. (2011) \\
\hline Mixed plantation & $35^{\circ} 01^{\prime} \mathrm{N}$ & 1196 & 579 & 1.90 & Tong et al. (2014) \\
\hline Moso Bamboo forest & $30^{\circ} 28^{\prime} \mathrm{N}$ & $1522 \pm 73$ & $693 \pm 41$ & $2.21 \pm 0.23$ & This study \\
\hline
\end{tabular}




\subsection{Future Work and Prospect}

$\mathrm{CO}_{2}$ and water vapor fluxes were measured by the EC method during the period 2011 - 2014 over a moso bamboo forest at AJ. The seasonal and interannual variation in GPP, ET, and WUE for a bamboo forest located in southeastern China was examined and the environmental variable effects on GPP, ET, and WUE were explored. During the study period a summer drought provided us with a good opportunity to explore the summer drought effect on the carbon and water cycles. As the measurement time series was short (only four years available), the effects of other environmental stress on the carbon and water fluxes were not observed, such as spring drought. In Northeast China, Dong et al. (2011) found a reduction in WUE for a meadow steppe ecosystem caused by a severe spring drought. Further studies on the impact of spring drought on WUE for the bamboo forest ecosystem are needed to provide comprehensive studies of the effects of other environmental stresses on carbon and water fluxes. Further studies will improve our understanding of how future climate change will affect the carbon and water cycles of ecosystems. In the present study we estimated GPP, ET, and WUE at the monthly scale. Using a higher resolution, for example, at the minute scale or at the daily scale, will reveal more information about carbon and water cycles. In further studies, our results could be combined with the network EC measurements or remote sensing techniques, which will provide temporal and spatial information about carbon and water cycles.

Acknowledgements Funding support partially from the NSF China Major Program (61190114 \& 41171324) and The State Key Fundamental Science Funds of China (2011CB302705, 2010CB950702, and 2010CB428503), The Funds for Ph.D. Education (20110091110028), The fundamental research project of MOST (2005DKA32300), The Priority Academic Program Development of Jiangsu Higher Education Institutions, Zhejiang province key science and technology innovation team (2010R50030). Supported by the program B for Outstanding Ph.D. candidate of Nanjing University.

\section{REFERENCES}

Arain, M. A. and N. Restrepo-Coupe, 2005: Net ecosystem production in a temperate pine plantation in southeastern Canada. Agric. For. Meteorol., 128, 223-241, doi: 10.1016/j.agrformet.2004.10.003. [Link]

Beer, C., M. Reichstein, P. Ciais, G. D. Farquhar, and D. Papale, 2007: Mean annual GPP of Europe derived from its water balance. Geophys. Res. Lett., 34, L05401, doi: 10.1029/2006GL029006. [Link]

Beer, C., P. Ciais, M. Reichstein, D. Baldocchi, B. E. Law, D. Papale, J. F. Soussana, C. Ammann, N. Buchmann, D.
Frank, D. Gianelle, I. A. Janssens, A. Knohl, B. Köstner, E. Moors, O. Roupsard, H. Verbeeck, T. Vesala, C. A. Williams, and G. Wohlfahrt, 2009: Temporal and among-site variability of inherent water use efficiency at the ecosystem level. Global Biogeochem. Cycles, 23, GB2018, doi: 10.1029/2008GB003233. [Link]

Beer, C., M. Reichstein, E. Tomelleri, P. Ciais, M. Jung, N. Carvalhais, C. Rödenbeck, M. A. Arain, D. Baldocchi, G. B. Bonan, A. Bondeau, A. Cescatti, G. Lasslop, A. Lindroth, M. Lomas, S. Luyssaert, H. Margolis, K. W. Oleson, O. Roupsard, E. Veenendaal, N. Viovy, C. Williams, F. I. Woodward, and D. Papale, 2010: Terrestrial gross carbon dioxide uptake: Global distribution and covariation with climate. Science, 329, 834838, doi: 10.1126/science.1184984. [Link]

Brümmer, C., T. A. Black, R. S. Jassal, N. J. Grant, D. L. Spittlehouse, B. Chen, Z. Nesic, B. D. Amiro, M. A. Arain, A. G. Barr, C. P. A. Bourque, C. Coursolle, A. L. Dunn, L. B. Flanagan, E. R. Humphreys, P. M. Lafleur, H. A. Margolis, J. H. McCaughey, and S. C. Wofsy, 2012: How climate and vegetation type influence evapotranspiration and water use efficiency in Canadian forest, peatland and grassland ecosystems. Agric. For. Meteorol., 153, 14-30, doi: 10.1016/j.agrformet.2011.04.008. [Link]

Cai, T., D. T. Price, A. L. Orchansky, and B. R. Thomas, 2011: Carbon, water, and energy exchanges of a hybrid poplar plantation during the first five years following planting. Ecosystems, 14, 658-671, doi: 10.1007/ s10021-011-9436-8. [Link]

Chen, X., X. Zhang, Y. Zhang, T. Booth, and X. He, 2009: Changes of carbon stocks in bamboo stands in China during 100 years. For. Ecol. Manage., 258, 1489-1496, doi: 10.1016/j.foreco.2009.06.051. [Link]

Dong, G., J. Guo, J. Chen, G. Sun, S. Gao, L. Hu, and Y. Wang, 2011: Effects of spring drought on carbon sequestration, evapotranspiration and water use efficiency in the Songnen meadow steppe in Northeast China. Ecohydrology, 4, 211-224, doi: 10.1002/eco.200. [Link]

Falge, E., D. Baldocchi, R. Olson, P. Anthoni, M. Aubinet, C. Bernhofer, G. Burba, R. Ceulemans, R. Clement, H. Dolman, A. Granier, P. Gross, T. Grünwald, D. Hollinger, N. O. Jensen, G. Katul, P. Keronen, A. Kowalski, C. T. Lai, B. E. Law, T. Meyers, J. Moncrieff, E. Moors, J. W. Munger, K. Pilegaard, Ü. Rannik, C. Rebmann, A. Suyker, J. Tenhunen, K. Tu, S. Verma, T. Vesala, K. Wilson, and S. Wofsy, 2001: Gap filling strategies for defensible annual sums of net ecosystem exchange. Agric. For. Meteorol., 107, 43-69, doi: 10.1016/S0168-1923(00)00225-2. [Link]

Farquhar, G. D. and R. A. Richards, 1984: Isotopic composition of plant carbon correlates with water-use efficiency of wheat genotypes. Aust.J. Plant Physiol., 11, 539-552, doi: 10.1071/PP9840539. [Link] 
Ge, Z. M., S. Kellomäki, X. Zhou, and H. Peltola, 2014: The role of climatic variability in controlling carbon and water budgets in a boreal Scots pine forest during ten growing seasons. Boreal Environ. Res., 19, 181-194.

Hu, Z., G. Yu, Y. Fu, X. Sun, Y. Li, P. Shi, Y. Wang, and Z. Zheng, 2008: Effects of vegetation control on ecosystem water use efficiency within and among four grassland ecosystems in China. Global Change Biol., 14, 16091619, doi: 10.1111/j.1365-2486.2008.01582.x. [Link]

Jassal, R. S., T. A. Black, D. L. Spittlehouse, C. Brümmer, and Z. Nesic, 2009: Evapotranspiration and water use efficiency in different-aged Pacific Northwest Douglas-fir stands. Agric. For. Meteorol., 149, 1168-1178, doi: 10.1016/j.agrformet.2009.02.004. [Link]

Kotani, A., A. V. Kononov, T. Ohta, and T. C. Maximov, 2014: Temporal variations in the linkage between the net ecosystem exchange of water vapour and $\mathrm{CO}_{2}$ over boreal forests in eastern Siberia. Ecohydrology, 7, 209225, doi: 10.1002/eco.1449. [Link]

Kuglitsch, F. G., M. Reichstein, C. Beer, A. Carrara, R. Ceulemans, A. Granier, I. A. Janssens, B. Koestner, A. Lindroth, D. Loustau, G. Matteucci, L. Montagnani, E. J. Moors, D. Papale, K. Pilegaard, S. Rambal, C. Rebmann, E. D. Schulze, G. Seufert, H. Verbeeck, T. Vesala, M. Aubinet, C. Bernhofer, T. Foken, T. Grünwald, B. Heinesch, W. Kutsch, T. Laurila, B. Longdoz, F. Miglietta, M. J. Sanz, and R. Valentini, 2008: Characterisation of ecosystem water-use efficiency of European forests from eddy covariance measurements. Biogeosciences Discuss., 5, 4481-4519, doi: 10.5194/ bgd-5-4481-2008. [Link]

Lasslop, G., M. Reichstein, D. Papale, A. D. Richardson, A. Arneth, A. Barr, P. Stoy, and G. Wohlfahrt, 2010: Separation of net ecosystem exchange into assimilation and respiration using a light response curve approach: Critical issues and global evaluation. Global Change Biol., 16, 187-208, doi: 10.1111/j.1365-2486.2009.02041.x. [Link]

Law, B. E., E. Falge, L. Gu, D. D. Baldocchi, P. Bakwin, P. Berbigier, K. Davis, A. J. Dolman, M. Falk, J. D. Fuentes, A. Goldstein, A. Granier, A. Grelle, D. Hollinger, I. A. Janssens, P. Jarvis, N. O. Jensen, G. Katul, Y. Mahli, G. Matteucci, T. Meyers, R. Monson, W. Munger, W. Oechel, R. Olson, K. Pilegaard, K. T. Paw U, H. Thorgeirsson, R. Valentini, S. Verma, T. Vesala, K. Wilson, and S. Wofsy, 2002: Environmental controls over carbon dioxide and water vapor exchange of terrestrial vegetation. Agric. For. Meteorol., 113, 97120, doi: 10.1016/S0168-1923(02)00104-1. [Link]

Lu, X. and Q. Zhuang, 2010: Evaluating evapotranspiration and water-use efficiency of terrestrial ecosystems in the conterminous United States using MODIS and AmeriFlux data. Remote Sens. Environ., 114, 19241939, doi: 10.1016/j.rse.2010.04.001. [Link]
Lu, X., H. Jiang, J. Liu, C. Sun, Y. Wang, and J. Jin, 2014: Comparing simulated carbon budget of a Lei bamboo forest with flux tower data. Terr. Atmos. Ocean. Sci., 25, 359-368, doi: 10.3319/TAO.2014.01.13.01(TT). [Link]

McMillen, R. T., 1988: An eddy correlation technique with extended applicability to non-simple terrain. Bound.Layer Meteor., 43,231-245, doi: 10.1007/BF00128405. [Link]

Mi, N., X. Wen, F. Cai, Y. Wang, and Y. Zhang, 2014: Effects of seasonal drought on the water use efficiency of Qianyanzhou plantation. Scientia Silvae Sinicae, 50, 24-31, doi: 10.11707/j.1001-7488.20141204. [Link]

Ponton, S., L. B. Flanagan, K. P. Alstad, B. G. Johnson, K. Morgenstern, N. Kljun, T. A. Black, and A. G. Barr, 2006: Comparison of ecosystem water-use efficiency among Douglas-fir forest, aspen forest and grassland using eddy covariance and carbon isotope techniques. Global Change Biol., 12, 294-310, doi: 10.1111/j.13652486.2005.01103.x. [Link]

Reichstein, M., J. D. Tenhunen, O. Roupsard, J. M. Ourcival, S. Rambal, F. Miglietta, A. Peressotti, M. Pecchiari, G. Tirone, and R. Valentini, 2002: Severe drought effects on ecosystem $\mathrm{CO}_{2}$ and $\mathrm{H}_{2} \mathrm{O}$ fluxes at three Mediterranean evergreen sites: Revision of current hypotheses? Global Change Biol., 8, 999-1017, doi: 10.1046/j.1365-2486.2002.00530.x. [Link]

Reichstein, M., E. Falge, D. Baldocchi, D. Papale, M. Aubinet, P. Berbigier, C. Bernhofer, N. Buchmann, T. Gilmanov, A. Granier, T. Grünwald, K. Havránková, H. Ilvesniemi, D. Janous, A. Knohl, T. Laurila, A. Lohila, D. Loustau, G. Matteucci, T. Meyers, F. Miglietta, J. M. Ourcival, J. Pumpanen, S. Rambal, E. Rotenberg, M. Sanz, J. Tenhunen, G. Seufert, F. Vaccari, T. Vesala, D. Yakir, and R. Valentini, 2005: On the separation of net ecosystem exchange into assimilation and ecosystem respiration: Review and improved algorithm. Global Change Biol., 11, 1424-1439, doi: 10.1111/j.1365-2486.2005.001002.x. [Link]

Reichstein, M., P. Ciais, D. Papale, R. Valentini, S. Running, N. Viovy, W. Cramer, A. Granier, J. Ogée, V. Allard, M. Aubinet, C. Bernhofer, N. Buchmann, A. Carrara, T. Grünwald, M. Heimann, B. Heinesch, A. Knohl, W. Kutsch, D. Loustau, G. Manca, G. Matteucci, F. Miglietta, J. M. Ourcival, K. Pilegaard, J. Pumpanen, S. Rambal, S. Schaphoff, G. Seufert, J. F. Soussana, M. J. Sanz, T. Vesala, and M. Zhao, 2007: Reduction of ecosystem productivity and respiration during the European summer 2003 climate anomaly: A joint flux tower, remote sensing and modelling analysis. Global Change Biol., 13, 634-651, doi: 10.1111/j.13652486.2006.01224.x. [Link]

Rodrigues, A., G. Pita, J. Mateus, C. Kurz-Besson, M. Casquilho, S. Cerasoli, A. Gomes, and J. Pereira, 2011: 
Eight years of continuous carbon fluxes measurements in a Portuguese eucalypt stand under two main events: Drought and felling. Agric. For. Meteorol., 151, 493507, doi: 10.1016/j.agrformet.2010.12.007. [Link]

Scanlon, T. M. and J. D. Albertson, 2004: Canopy scale measurements of $\mathrm{CO}_{2}$ and water vapor exchange along a precipitation gradient in southern Africa. Global Change Biol., 10, 329-341, doi: 10.1046/j.13652486.2003.00700.x. [Link]

Song, X., G. Yu, Y. Liu, X. Sun, Y. Lin, and X. Wen, 2006: Seasonal variations and environmental control of water use efficiency in subtropical plantation. Sci. China Ser. D, 49, 119-126, doi: 10.1007/s11430-006-8319-X. [Link]

Tang, X., H. Li, A. R. Desai, Z. Nagy, J. Luo, T. E. Kolb, A. Olioso, X. Xu, L. Yao, W. Kutsch, K. Pilegaard, B. Köstner, and C. Ammann, 2014: How is water-use efficiency of terrestrial ecosystems distributed and changing on Earth? Sci. Rep., 4, doi: 10.1038/srep07483. [Link]

Testi, L., F. Orgaz, and F. Villalobos, 2008: Carbon exchange and water use efficiency of a growing, irrigated olive orchard. Environ. Exp. Bot., 63, 168-177, doi: 10.1016/j.envexpbot.2007.11.006. [Link]

Thomas, C. K., B. E. Law, J. Irvine, J. G. Martin, J. C. Pettijohn, and K. J. Davis, 2009: Seasonal hydrology explains interannual and seasonal variation in carbon and water exchange in a semiarid mature ponderosa pine forest in central Oregon. J. Geophys. Res., 114, G04006, doi: 10.1029/2009JG001010. [Link]

Tong, X. J., J. Li, Q. Yu, and Z. Qin, 2009: Ecosystem water use efficiency in an irrigated cropland in the North China Plain. J. Hydrol., 374, 329-337, doi: 10.1016/j. jhydrol.2009.06.030. [Link]

Tong, X. J., J. Zhang, P. Meng, J. Li, and N. Zheng, 2014: Ecosystem water use efficiency in a warm-temperate mixed plantation in the North China. J. Hydrol., 512, 221-228, doi: 10.1016/j.jhydrol.2014.02.042. [Link]

Vickers, D., C. K. Thomas, C. Pettijohn, J. G. Martin, and B. E. Law, 2012: Five years of carbon fluxes and inherent water-use efficiency at two semi-arid pine forests with different disturbance histories. Tellus B, 64, 17159, doi: 10.3402/tellusb.v64i0.17159. [Link]

Wang, F., H. Jiang, X. Zhang, 2015: Spatial-temporal dynamics of gross primary productivity, evapotranspiration, and water-use efficiency in the terrestrial ecosystems of the Yangtze River Delta region and their relations to climatic variables. Int. J. Remote Sens., 36, 2654-2673, doi: 10.1080/01431161.2015.1041618. [Link]

Webb, E. K., G. I. Pearman, R. Leuning, 1980: Correction of flux measurements for density effects due to heat and water vapour transfer. Q.J.R.Meteorol.Soc., 106, 85-100, doi: 10.1002/qj.49710644707. [Link]

Yang, B., S. G. Pallardy, T. P. Meyers, L. H. Gu, P. J. Hanson, S. D. Wullschleger, M. Heuer, K. P. Hosman, J. S. Riggs, and D. W. Sluss, 2010: Environmental controls on water use efficiency during severe drought in an Ozark Forest in Missouri, USA. Global Change Biol., 16, 2252-2271, doi: 10.1111/j.13652486.2009.02138.x. [Link]

Yu, G. R., Q. F. Wang, and J. Zhuang, 2004: Modeling the water use efficiency of soybean and maize plants under environmental stresses: Application of a synthetic model of photosynthesis-transpiration based on stomatal behavior. J. Plant Physiol., 161, 308-318, doi: 10.1078/0176-1617-00972. [Link]

Yu, G. R., X. Song, Q. Wang, Y. Liu, D. Guan, J. Yan, X. Sun, L. Zhang, and X. Wen, 2008: Water-use efficiency of forest ecosystems in eastern China and its relations to climatic variables. New Phytologist, 177, 927-937, doi: 10.1111/j.1469-8137.2007.02316.x. [Link]

Zeri, M., L. D. A. Sá, A. O. Manzi, A. C. Araújo, R. G. Aguiar, C. von Randow, G. Sampaio, F. L. Cardoso, and C. A. Nobre, 2014: Variability of carbon and water fluxes following climate extremes over a tropical forest in southwestern Amazonia. PLoS ONE, 9, doi: 10.1371/journal.pone.0088130. [Link]

Zhao, F. H., G. R. Yu, S. G. Li, C. Y. Ren, X. M. Sun, N. Mi, J. Li, and Z. Ouyang, 2007: Canopy water use efficiency of winter wheat in the North China Plain. Agric. Water Manage., 93, 99-108, doi: 10.1016/j.agwat.2007.06.012. [Link]

Zhou, G. and P. Jiang, 2004: Density, storage and spatial distribution of carbon in Phyllostachy Pubescens forest. Scientia Silvae Sinicae, 40, 20-24, doi: 10.11707/ j.1001-7488.20040604. [Link]

Zhou, J., Z. Zhang, G. Sun, X. Fang, T. Zha, J. Chen, A. Noormets, J. Guo, and S. McNulty, 2014: Water-use efficiency of a poplar plantation in Northern China. J. For. Res., 19, 483-492, doi: 10.1007/s10310-0140436-3. [Link]

Zhu, X., G. Yu, Q. Wang, Z. Hu, S. Han, J. Yan, Y. Wang, and L. Zhao, 2014: Seasonal dynamics of water use efficiency of typical forest and grassland ecosystems in China. J. For. Res., 19, 70-76, doi: 10.1007/s10310013-0390-5. [Link]

Zhu, X. J., G. R. Yu, Q. F. Wang, Z. M. Hu, H. Zheng, S. G. Li, X. M. Sun, Y. P. Zhang, J. H. Yan, H. M. Wang, F. H. Zhao, J. H. Zhang, P. L. Shi, Y. N. Li, L. Zhao, F. W. Zhang, and Y. B. Hao, 2015: Spatial variability of water use efficiency in China's terrestrial ecosystems. Global Planet. Change, 129, 37-44, doi: 10.1016/j.gloplacha.2015.03.003. [Link] 